\title{
A DEVELOPMENT STRATEGY FOR DAIRY GOAT FARMS IN BOGOR REGENCY - WEST JAVA
}

\author{
L. Cyrilla ${ }^{1}$, B. P. Purwanto ${ }^{2}$, A. Atabany ${ }^{1}$, D. A. Astuti ${ }^{1}$ and A. Sukmawati ${ }^{3}$ \\ ${ }^{1}$ Faculty of Animal Science, Bogor Agricultural University, \\ Jl Agatis, Darmaga Campus, Bogor 16680 - Indonesia, \\ ${ }^{2}$ Directorate of Diploma Program, Bogor Agricultural University, \\ Jl. Kumbang No. 14, Bogor 16151 - Indonesia \\ ${ }^{3}$ Faculty of Economics and Management, Bogor Agricultural University, \\ Jl Kamper Darmaga Campus, Bogor 16680 - Indonesia \\ Corresponding E-mail:cyrilla_lucia@yahoo.com \\ Received May 17, 2016; Accepted July 26, 2016
}

\begin{abstract}
ABSTRAK
Penelitian ini bertujuan untuk mengidentifikasi faktor-faktor yang terkait dengan peternakan kambing perah untuk selanjutnya merumuskan strategi pengembangan yang mampu mendukung agribisnis susu kambing khususnya untuk Kabupaten Bogor. Penelitian dilaksanakan di 3 (tiga) peternakan kambing perah yang ada di Kabupaten Bogor. Penentuan sampel peternak dilakukan secara purposive yaitu peternakan kambing perah rakyat skala menengah yang memiliki populasi kambing perah lebih dari 100 ekor dan telah berdiri lebih dari 10 tahun. Pengumpulan data dilakukan selama bulan Februari - Mei 2014. Disain yang digunakan dalam penelitian ini adalah penelitian deskriptif kualitatif dengan pendekatan cepat (rapid appraisal). Analisis data menggunakan Evaluasi Faktor Internal dan Evaluasi Faktor Eksternal, Matriks Strategic Position and Action Evaluation (SPACE) dan Matriks Grand strategy. Posisi strategis peternakan kambing perah di Kabupaten Bogor berada pada strategi agresif dalam SPACE matrix. Meskipun menghadapi berbagai ancaman, peternakan kambing perah di Kabupaten Bogor memiliki keunggulan sumberdaya. Analisis Grand Strategy Matrix menunjukkan peternakan kambing perah berada dalam posisi yang sangat bagus untuk memanfaatkan berbagai kekuatan internalnya untuk menarik keuntungan dari peluang-peluang eksternal, mengatasi kelemahan internal, dan menghindari beragam ancaman eksternal. Strategi terbaik yang berpeluang besar dipilih untuk peternakan kambing perah adalah penetrasi pasar dan pengembangan produk.

Kata kunci: kambing perah, strategi pengembangan, faktor internal, faktor eksternal SPACE Matrix, Grand Strategy Matrix
\end{abstract}

\begin{abstract}
The objectives of present study were to formulate development strategies for dairy goat' farms that capable of supporting goat's milk agribusiness. Three medium scale dairy goat farms located in Bogor Regency which has population of more than 100 heads and has established more than 10 years were purposively selected for the study. Data were collected during February to May 2014. The design of this study was based on descriptive qualitative approach (rapid appraisal approach). Data were analized using internal factors evaluation (IFE) and external factors evaluation (EFE), strategic position and action evaluation (SPACE) matrix, and grand strategy matrix. It was revealed that dairy goat farms in Bogor Regency were located in quadrant I in SPACE matrix, which was on the aggressive strategy. Dairy goat farms have many resource advantages, despite facing various threats. The Grand Strategy
\end{abstract}


Matrix analysis showed that dairy goat farms were in quadrant I. Dairy goat farms were in an excellent position to take advantage of the opportunities, overcome internal weaknesses and avoiding multiple external threats. The best strategies to be selected for dairy goat farms were market penetration and product development.

Keywords: dairy goat, development strategy, Internal Factor, External Factor, SPACE Matrix, Grand Strategy Matrix

\section{INTRODUCTION}

Goat population in Indonesia has increased in the last four years, from 16.9 million heads in 2011 to 18.6 million heads in 2014 . Only about 32 percent of the total goat population was dairy goat type (Astuti, 2013). West Java Province has third largest population of goats in Indonesia after East Java and Central Java. Bogor Regency is one of goat farms center in West Java. Population of Ettawa Grade (Peranakan Etawah) goat in Bogor Regency in 2014 was about 6517 heads (BPS, 2015). These goats were centralized in several district such as Tamansari, Caringin, Cijeruk, Cigombong, Ciampea, Babakan Madang and Sukamakmur. Dairy goat farm has a major role in supporting economic activities in Bogor. Goat raising in Bogor Regency is mostly managed by the community. Female goat maintained primarily for the purpose of being milked and kidding, while a small portion of male goats were maintained for the contest livestock purpose.

The development of dairy goat farms was aimed to enhance and exploit the available potential to increase milk production and processed products in the country (Ditjen Agro Industri dan Kimia 2009; Ditjen Peternakan dan Kesehatan Hewan 2011). Consumer interest to goat's milk today mainly because of the goat milk is believed to have many benefits, especially in terms of health. Goats' milk production is fundamental to the wellbeing of thousands of Indonesian. Food processing on milk goat is currently at the stage of fermentation by adding lactic acid bacteria to the milk. Whereas for non food products, goat's milk is a common ingredient found in natural skin care and cosmetic products. So far, there are inadequate knowledge for further process as there are limitations of availability of both the quantity and quality the raw material.

Despite a great opportunity and potential for dairy goat rearing for the welfare of farmers in Indonesia, commercialization of milk goat production potential is still unfocus. Changing the mind set of farmers to start and focus on areas of business is crucial. Commercialization can be defined as an effort to enhance value added of its products, and they measure or judge them based on money. Dairy goat production, especially pasture-based production, offer the opportunity for profitable and sustainable diversity on a small farm (Costa et al., 2010; Midau et al., 2010; Delaney, 2012; Lie et al., 2012; Shahroudi and Naimi, 2014; Utami, 2014). Dairy goat farms have been established in the agroecosystem areas. The goat industry in Indonesia has continuously grown as local demand for milk increases. However, the industry can develop if both the government and private sectors provide support and focus on increasing dairy goat, particularly to improve the creativity of dairy goats' farmers to compete in satisfying their prospective consumers.

To analyze the position of a product or service in the the competitive environment where the business operates is very important for business competition. Such important knowledge may include information about what the customer needs, companies' resources, product pricing, production capacity, state of the marketing network, the state of the supplier network, things will be done by the competitors, as well as the opportunities that may exist (Astuti et al., 2010; Deshpande, 2012; Nurlaelasari et al. 2014). If a company acquire such knowledge and manage them effectively, the company's competitive advantage will be achieved easily. Strategy is a choice about the actions taken by the organization to achieve its objectives and to achieve competitive advantage. Its commitment to pursue a particular set of actions in growing the business, staking out a market position, attracting and pleasing customers, competing successfully, conducting operations and achieving targeted objectives (Wheelen and Hunger, 2010; Aisyah et al., 2013).

The objective of this study was to identify factors associated with dairy goat farms development, and then based on such factors this study will recommend the future strategies to develop modern dairy goat farms capable of supporting goat's milk agribusiness, especially in 
Bogor Regency.

\section{MATERIALS AND METHODS}

\section{Place and Time of Research}

The study was conducted on Bogor Regency, West Java Province. A purposive sampling design (Ishak and Bakar, 2014) was used to collect data. Three medium scale dairy goat farms located in Bogor Regency which has population of more than 100 heads and has established more than 10 years were selected for the study. Data collection was conducted on February to May 2014.

\section{Research Design}

The design of the present study was based on the qualitative approach using the Rapid Appraisal method (Cox, 2015). This method can be used to quickly obtain basic information appraisal, as they is relevant, timely, accurate and usable. Some basic principles of rapid appraisal are: listen and learn, using a diversified approach, avoiding formality, optimize information, using indicators reflection and minimize bias. Focused group discussion held with stakeholders associated with dairy goats' agribusiness for goat milk. The data were collected using semi-structured questionnaires through interviews. In-depth interviews (depth study) were also carried out to some key informants to explore expanded information. The data collected in this study consisted of:

1. Characteristics of dairy goats raised and its milk production, include: breeds, age, status of lactation, health status, individual milk production (liters per day, liters per period), the quality of milk (specific gravity, total solid, fat content).

2. Characteristics of dairy goat business, including: location (altitude, ambient temperature, humidity, type of soil, water conditions, area etc.), dairy goat ownership (including the composition of herds), the quantity and quality of inputs and its prices (feed, manpower, housing facilities, etc.), management (pregnant herds management, lactating mother, goat kids, buck, etc.; feeding and milking management).

3. Characteristics of farmers, including gender, age, educational background (formal and non-formal), business objectives (motivation, production targets, etc.).

4. Characteristics of dairy production and products, namely: the quantity of milk (total production, average production), volume and composition of milk produced (fresh milk and dairy products), the quality of milk (specific density, fat, protein, dry matter), marketing and distribution of dairy products, consumers (type and location of the consumer), goat milk demands the number of requests (liter per day, liter per month), the price of milk (at any level marketing agencies), marketing strategy (concept of 4P, type, category and location of marketing agencies).

5. Local government policies and regulations.

\section{Data Analysis Methods}

Data analyzed were presented in the table for subsequent identification of internal and external factors in the development of dairy goat farms as the first stage in strategic formulation. When the strategic factors were identified, an evaluation table for both internal factors and external factors were prepared to be analyzed for its strengths, weaknesses, opportunities and threats of dairy goat businesses (David et al., 2009; Wheelen and Hunger, 2010). It is very important as farm business manager must be capable of competing effectively in the existing business environment.

\section{Competitive Profile Matrix (CPM).}

In order to better understand the external environment and the competition in a particular industry, firms often use competitive profile matrix (CPM) (Hartono, 2011; Capps and Glissmeyer, 2012). The matrix identifies a firm's key competitors and compares them using industry's critical success factors (CSF). The analysis also reveals company's relative strengths and weaknesses against its competitors, so a company would know, which areas it should improve and, which areas to protect. Critical success factors (CSF) are the key areas, which must be performed at the highest possible level of excellence if organizations want succeed in the particular industry. They vary between different industries and include both internal and external factors. The more critical success factors are included the more robust and accurate the analysis is.

\section{Strategic Position and Action Evaluation and Grand Strategy Matrix}

The final stage on the strategic planning preparation will be identifying and prioritizing the 
business goals of the farm. At this stage, SPACE matrix and grand strategy matrix are used to determine the process of strategy formulation (David et al., 2009; Harisudin, 2011; Safari et al., 2013).

SPACE Matrix is broken down to four quadrants where each quadrant suggests: (1) financial strength (FS): includes measures to show the financial strength of the company, such as: profitability, liquidity, cash flow, economies of scale; (2) industrial strength (IS): includes measures to show the strength of the industry or business enterprises, such as: potential growth, technology, productivity, and capital intensity; (3) competitive advantage (CA): includes measures to describe competitive advantage of the company, such as product quality, customer loyalty, market share, the capital utility; and (4) environment stability (ES): includes measures to reflect all instability corporate environment, including: changes in technology, the rate of inflation, market reduncies, the intensity of competition. The financial strength and competitive advantage are the two factors that determine the position of the company's strategy, while the industrial strength and stability of the environment shows the characteristic position overall industrial strategy (Borocki, 2011; Harisudin, 2011).

\section{A Grand Strategy Matrix is a Tool Used by Businesses to Devise Alternative Strategies}

The matrix is primarily based on four essential elements: rapid market growth, slow market growth, strong competitive position and weak competitive position. These four elements make up a four-quadrant strategy matrix in which every organization or company division is placed for easy identification of the best strategy based on the company's competitive state and growth. The task of choosing an appropriate strategy lies in the hands of the management. The four elements of a grand strategy matrix are generally considered as evaluative dimensions of competitive position and market and market growth. Businesses use this method to plan effective strategies (David et al. 2009; Wheelen and Hunger, 2010; O’Regan et al., 2012.).

\section{RESULTS AND DISCUSSION}

\section{Studied Farms General Overview}

Farm A was located in the district of Cariu District Bogor Regency West Java. The altitude was about $400 \mathrm{~m}$ above sea level. Total area that farm owned was about 4.7 ha. The land was used for livestock housing and barn, employee' house and dormitory, offices and warehouses, and Napier grass orchards as well. The rest of the land is used for sengon (Paraserianthes falcataria) cultivation. The farm was established in 1999 after the owner received raising dairy goats training. Farm B was located in Cijeruk District Bogor Regency. The altitude of region around the farm was about 500-600 $\mathrm{m}$ above sea level with hilly topography and the land slope was quite varied. The average temperature was $24.9^{\circ} \mathrm{C}$, and average humidity in this region was quite high (83.4\%). Farm C was located in the Tamansari District, Bogor Regency. The altitude was $700 \mathrm{~m}$ above sea level, the temperature of the environment around $22-26{ }^{\circ} \mathrm{C}$ and the humidity was about $70-80 \%$. This farm was founded in 2007 as the owner likes to keep livestock. Total area owned by Farm C was 11.5 ha. Livestock houses at Farm $\mathrm{C}$ were built on the cliffs and terraced, follow the land contours.

Table 1 shows the breeds of dairy goats raised were Saanen, Ettawa or Ettawa crossbred (Peranakan Etawah or PE). The age of dairy goats were between $2.5-3$ years $\left(\mathrm{I}_{2}-\mathrm{I}_{3}\right)$, or in the second and third lactation. Farm A provides their goats with Napier grass (Pennisetum purpureum),

Table 1. Dairy Goat Composition on Studied Farms

\begin{tabular}{cccccc}
\hline \multirow{2}{*}{ Farm code } & $\begin{array}{c}\text { Number of } \\
\text { lactation goat } \\
\text { (head) }\end{array}$ & $\begin{array}{c}\text { Percentage of } \\
\text { lactation goat (\%) }\end{array}$ & \multicolumn{2}{c}{ Dairy goat population (head) } \\
\cline { 5 - 6 } & 90 & 67 & 54 & 203 & Altawa Grade \\
A & 22 & 49 & 130 & Saanen/ Sapera & 22 \\
B & 44 & 63 & 154 & - & 3 \\
C & 40 & & & \\
\hline
\end{tabular}


field grass and other forages, and concentrates (i.e. dregs of beer, tofu waste or bran) as well. On the average of $4-5 \mathrm{~kg} /$ day of forage and approximately $400-500 \mathrm{~g} / \mathrm{day}$ concentrates are given as goat daily intake. Whereas farm $\mathrm{B}$ gives concentrate mixed with cassava, bran, pulp. In addition, forages consisted of grass and leaves of cassava, calliandra, gliricidia and indigofera are also given. Farm $\mathrm{C}$ feeds its goats with forages and concentrates which contain soybean cake waste, tofu waste, palm waste, and black cumin (habatussauda). Ready-made concentrate are also given.

Cyrilla et al. (2015) has reported that goat milk produced by dairy goat farms in Bogor Regency have met Indonesia fresh milk standard (SNI 3141.1:2011) and Thai Agricultural Standard of Raw Goat Milk as well, particularly in the basic components, i.e. specific gravity, total solid, fat, protein and total solid non-fat. Moreover, further analysis of its fat and protein content, goat milk from those farms could be classified into the premium category (Table 2 ).

Goat milk price produces in farm $\mathrm{A}$ is IDR30,000/liter, IDR27,500/liter in farm B, and IDR 35,000/liter in farm C. Packaging size of goat milk sold to the consumer is 200 cc. For consumers relatively expensive price of goat milk if compared to cow milk won't be problem for them as long as they are convinced that consuming goat milk is beneficial for them.
Consumers expect that goat milk farmers guarantee the availability of goat milk at any time.

\section{Evaluation of Internal and External Factors for Dairy Goat Farms}

The analysis of internal factors (Table 3) shows that the primary internal factors affecting dairy goat farm is goat milk quality, and it obtained the highest weighted score $(0.236)$. Sustainability dairy goat business is highly dependent on consumer confidence in the quality of the goat milk produced by a farm. The study also revealed that all farms have produced good quality goat milk, and even considered to be in the premium category.

The second primary internal factors are the nature of farmers who are very creative, innovative and have entrepreneurial spirit. The dairy goat farmers are entrepreneurs who generally have sufficient capital to start their businesses. Most farmers are not from farmers' neigbourhood. They have keen senses to breed goats because they love animals. Farmers always wanted to learn innovations related to dairy goat farm. Farmers have always been learning and searching current information, and have built relationship with one that is knowledgeable about dairy goats. In fact, some farmers even developed collaboration with research institutes, and granted permissions for those institutions to conduct researches on their farms.

Table 2. Goat Milk Quality of Studied Farms

\begin{tabular}{|c|c|c|c|}
\hline Description & Farm A & Farm B & Farm C \\
\hline Breed of dairy goat & Saanen & PE \& Saanen & Etawah \& PE \\
\hline Population of lactation does (head) & 90 & 22 & 44 \\
\hline Milk production (liter/day) & $110 \pm 30$ & $22.2 \pm 2.5$ & $40.5 \pm 7.5$ \\
\hline Average milk production (liter/head/day) & $1.2 \pm 0.3$ & $0.9 \pm 0.25$ & $0.85 \pm 0.2$ \\
\hline \multicolumn{4}{|l|}{ Quality parameter } \\
\hline Specific gravity & $1.0295 \pm 0.0003$ & $1.0300 \pm 0.0002$ & $1.0300 \pm 0.0002$ \\
\hline Total solid (\%) & \pm 0.02 & \pm 0.01 & \pm 10.02 \\
\hline Fat $(\%)$ & \pm 0.4 & \pm 0.5 & \pm 0.5 \\
\hline Protein $(\%)$ & \pm 0.06 & \pm 0.03 & \pm 0.04 \\
\hline Total solid non-fat (\%) & \pm 0.04 & \pm 0.03 & \pm 0.04 \\
\hline
\end{tabular}

Source: Cyrilla et al. (2015)

*Analyzed in Dairy Production Laboratory, Department of Animal Production and Technology Faculty of Animal Science Bogor Agricultural University (2014) 
Table 3. Matrix Evaluation of the Internal Factors for Dairy Goat Farms

\begin{tabular}{|c|c|c|c|}
\hline Internal Factors & Weight & Rating & $\begin{array}{l}\text { Weighted } \\
\text { score }\end{array}$ \\
\hline \multicolumn{4}{|l|}{ Strength } \\
\hline Very creative farmers, have entrepreneurial innovation & 0.057 & 4 & 0.228 \\
\hline Goats' milk is highly nutritious & 0.059 & 4 & 0.236 \\
\hline The price of goat milk is relatively high & 0.052 & 3 & 0.156 \\
\hline Goat's milk become a niche market & 0.047 & 4 & 0.188 \\
\hline Farmers always updating the technology to be more efficient & 0.047 & 4 & 0.188 \\
\hline Each farm has its own 'unique' technology & 0.049 & 3 & 0.147 \\
\hline Take advantage many local feed resources & 0.045 & 3 & 0.135 \\
\hline $\begin{array}{l}\text { Have established good relationships with research institutions and } \\
\text { universities as well }\end{array}$ & 0.043 & 3 & 0.129 \\
\hline Having a good relationship with trusted suppliers & 0.052 & 4 & 0.208 \\
\hline Relatively better application of GDFP & 0.048 & 4 & 0.192 \\
\hline \multicolumn{4}{|l|}{ Weaknesses } \\
\hline Unclear job descriptions & 0.057 & 2 & 0.114 \\
\hline Skills and labor discipline is not optimal & 0.059 & 1 & 0.059 \\
\hline Processed products diversification is still limited & 0.052 & 2 & 0.104 \\
\hline Recording of financial data is incomplete & 0.047 & 2 & 0.094 \\
\hline The lack of proper marketing or products are not priced optimally & 0.052 & 1 & 0.052 \\
\hline Dairy goat milking facilities is still inadequate & 0.049 & 1 & 0.049 \\
\hline $\begin{array}{l}\text { They have not yet fully embraced the concept of environmentally } \\
\text { friendly practices }\end{array}$ & 0.046 & 2 & 0.092 \\
\hline $\begin{array}{l}\text { The processing technology for milk products is relatively } \\
\text { expensive }\end{array}$ & 0.048 & 2 & 0.096 \\
\hline Environmental carrying capacity of land decreases & 0.047 & 1 & 0.047 \\
\hline Limited access to technology & 0.044 & 2 & 0.088 \\
\hline Total & 1.000 & & 2.602 \\
\hline
\end{tabular}

Table 4 revealed that the main external factors affecting goat milk farms is customer satisfaction. These factors are opportunities for farmers to develop their businesses. This expression is supported by the sequence analysis of internal factors which was indicated that high quality goat milk is the main internal factor. However, the second main factor which constitutes threat to farmers is the continuity of replacement stocks availability from a supplier, as there is no guarantee for the quality of stocks supplies from dairy goat breeders. The necessary supervision of the competent authorities that is the government, to guarantee that the standards required by dairy goat farmers are met.

\section{Competitive Profile Matrix Analysis}

The competitive position of the three dairy goat farms studied is presented in Table 5. This condition was analyzed base on evaluation of internal and external factors. Based on the score obtained, Farm A seen to have higher compete ability compared to other farms (score 3.52). This competitive capability is supported by factors 
Table 4. Matrix Evaluation of the External Factors for Dairy Goat Farms

\begin{tabular}{|c|c|c|c|}
\hline External Factors & Weight & Rating & $\begin{array}{l}\text { Weighted } \\
\text { score }\end{array}$ \\
\hline \multicolumn{4}{|l|}{ Opportunities } \\
\hline Community awareness on healthy food & 0.057 & 3 & 0.171 \\
\hline High customers satisfaction & 0.059 & 4 & 0.236 \\
\hline High suppliers trust emerge & 0.052 & 3 & 0.156 \\
\hline The total number of competitors are relatively small & 0.047 & 3 & 0.141 \\
\hline $\begin{array}{l}\text { Goat milk processing into non-food products / products } \\
\text { diversification }\end{array}$ & 0.047 & 2 & 0.094 \\
\hline Markets expansion & 0.049 & 3 & 0.147 \\
\hline The development of information technology & 0.045 & 2 & 0.090 \\
\hline Increasing people's income & 0.043 & 2 & 0.086 \\
\hline Areas accessibility & 0.052 & 2 & 0.104 \\
\hline Development of the agribusiness areas & 0.048 & 3 & 0.144 \\
\hline \multicolumn{4}{|l|}{ Threats } \\
\hline Adulteration of goat's milk with other ingredients & 0.052 & 2 & 0.104 \\
\hline Competition with similar products from other regions & 0.059 & 3 & 0.177 \\
\hline Tends of the increasing prices for young stocks & 0.057 & 3 & 0.171 \\
\hline The continuity of young stocks availability & 0.052 & 4 & 0.208 \\
\hline No quality guarantee of young stocks from suppliers & 0.047 & 2 & 0.094 \\
\hline Competition with other sectors or land use for commodities & 0.049 & 2 & 0.098 \\
\hline Lack of government support & 0.045 & 2 & 0.090 \\
\hline No reliable institutional for goat breeders & 0.045 & 2 & 0.090 \\
\hline $\begin{array}{l}\text { Competition between animal feed ingredients with other animal } \\
\text { feeds }\end{array}$ & 0.047 & 3 & 0.141 \\
\hline Limited carrying capacity of the environment / nature & 0.048 & 2 & 0.096 \\
\hline Total & 1.000 & & 2.638 \\
\hline
\end{tabular}

such as organizational structure, human resources, product quality, production technology, marketing and promotion of the products, customer satisfaction and environmental supports.

It was identified that less supportive critical factor determinants for Farm B is the promotion and marketing of its products. Farm B mostly sells its goat milk product only to agent or reseller or to further processors. While the environment carrying capacity was identified as critical factor that weakened the support for Farm C. The environmental conditions where Farm $\mathrm{C}$ is located unable it to expand its business. Even the water source to supply Farm $\mathrm{C}$ needs has been claimed as the property to others. Farm $\mathrm{C}$ should look for other location with better environment carrying capacity to develop.

\section{Strategic Position and Action Evaluation Matrix Analysis}

The strategic position of the studied dairy goat farms were located in quadrant I (Figure 1). It tells that such dairy goat farms should pursue aggressive strategy in the SPACE matrix. The same condition is also occur for Farms A and B (Figure 2). Referring to the results of internal and 
Table 5. Competitive Profile Matrix (CPM) of Dairy Goat Farms in Bogor Regency

\begin{tabular}{|c|c|c|c|c|c|c|c|}
\hline \multirow{2}{*}{ Critical Decision Factors } & \multirow{2}{*}{ Value } & \multicolumn{2}{|c|}{ Farm A } & \multicolumn{2}{|c|}{ Farm B } & \multicolumn{2}{|c|}{ Farm C } \\
\hline & & Rating & Score & Rating & Score & Rating & Score \\
\hline $\begin{array}{l}\text { Organization structure of the } \\
\text { company }\end{array}$ & 0.07 & 4 & 0.29 & 3 & 0.22 & 3 & 0.22 \\
\hline Human resources & 0.09 & 4 & 0.37 & 4 & 0.37 & 3 & 0.28 \\
\hline Product quality & 0.09 & 4 & 0.36 & 3 & 0.27 & 3 & 0.27 \\
\hline Location of the farms & 0.07 & 3 & 0.22 & 3 & 0.22 & 3 & 0.22 \\
\hline $\begin{array}{l}\text { Production technology/ } \\
\text { management }\end{array}$ & 0.08 & 4 & 0.32 & 4 & 0.32 & 3 & 0.24 \\
\hline Product process & 0.09 & 3 & 0.26 & 4 & 0.34 & 4 & 0.34 \\
\hline $\begin{array}{l}\text { Marketing \& promotion of } \\
\text { products }\end{array}$ & 0.09 & 4 & 0.34 & 2 & 0.17 & 4 & 0.34 \\
\hline Consumer' satisfactions & 0.09 & 4 & 0.37 & 4 & 0.37 & 4 & 0.37 \\
\hline Input supplier & 0.09 & 3 & 0.26 & 4 & 0.34 & 4 & 0.34 \\
\hline Competitors & 0.09 & 3 & 0.26 & 3 & 0.26 & 3 & 0.26 \\
\hline Environmental supports & 0.08 & 4 & 0.33 & 4 & 0.33 & 2 & 0.17 \\
\hline Government regulations & 0.07 & 2 & 0.14 & 2 & 0.14 & 2 & 0.14 \\
\hline Total & 1.00 & & 3.52 & & 3.36 & & 3.19 \\
\hline
\end{tabular}

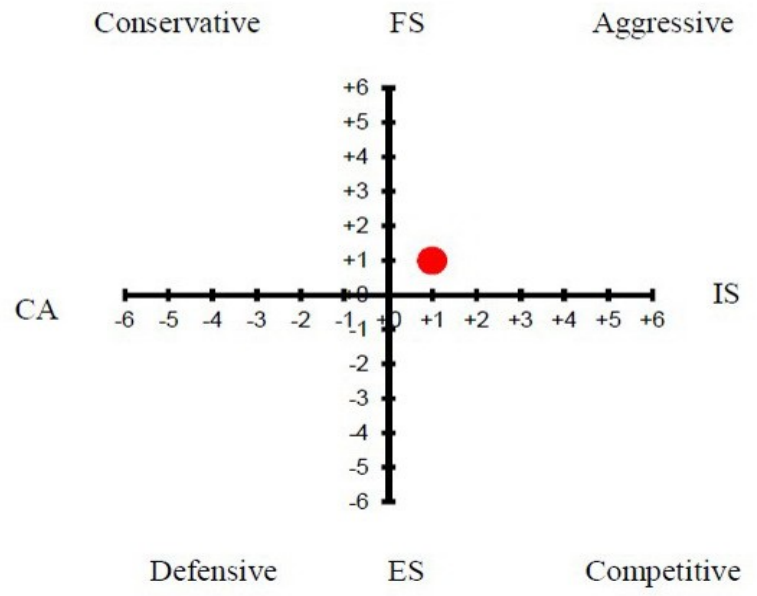

Figure 1. Strategic Position of Dairy Goat Farms in Bogor Regency based on SPACE Matrix. FS: Financial strength, CA: Competitive advantages, IS: Industry strength, ES: Environmental stability

external factors analysis this condition shows that dairy goat farms are in an excellent position to utilize its internal strengths, to take advantage of external opportunities, overcome internal weaknesses and avoiding multiple external threats. Therefore, a market penetration strategy is essentially a market share strategy, product development, backward integration, forward integration, horizontal integration, diversification, or a combination of all of them to be a reasonable option, depending on the specific situation encountered by the company.

Future horizontal integration is seeking ownership or increased control over a larger distributor. Currently more and more farm entrepreneurs run modern farm business integration strategy by developing websites to enable them selling their products directly to consumers. This strategy has already been practiced on the dairy goat farms we observed.

The other strategy that might be implemented by farms A and B will be market expansion of its products to other areas, diversification of goat milk products into food or non-food products, as well as the development of products that improve market value. Market 


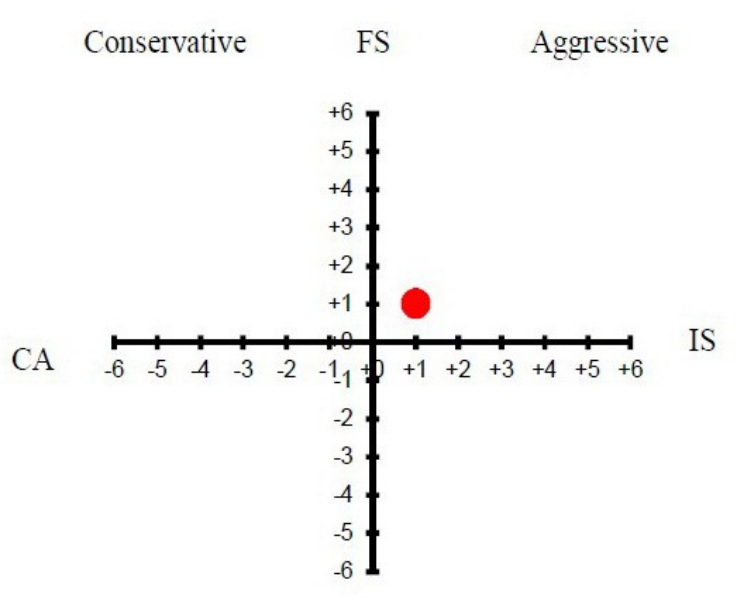

Defensive

ES

Competitive

Figure 2. Strategic Position of Farms A and B based on SPACE Matrix

penetration is strategy to improve the market share for the products or services in the market today through a larger marketing efforts. Market penetration include the addition of sales person, increasing advertising expenses, offering or sales promotion of products extensively.

Farms $\mathrm{C}$ is in quadrant IV in the SPACE Matrix that means this farm was in a competitive strategy (Figure 3). Competitive strategy includes backwards, forwards, and horizontal integration, market penetration, market development, product development, and joint venture. Competitive strategies are both either planned or unplanned strategy to have a competitive advantage that attract consumers' attention, strengthening position in the market, and withstand the pressures of competition, production inputs (raw materials and labor), product differentiation and niche market.

Competitive strategy will work properly if the company is capable to explain its long-term action plan that is devised to help a company gain a competitive advantage over its rival. This competitive advantage will allow the company to achieve greater profits than its rivals and strengthen its opportunity to operate longer in the competition. Some factors that support companies improving their competitive are: the marketdriven demand management includes sensing market conditions based on demand signals, then shaping demand, price and quality, and technology. There were three primary steps in this
Conservative $\quad$ FS $\quad$ Aggressive

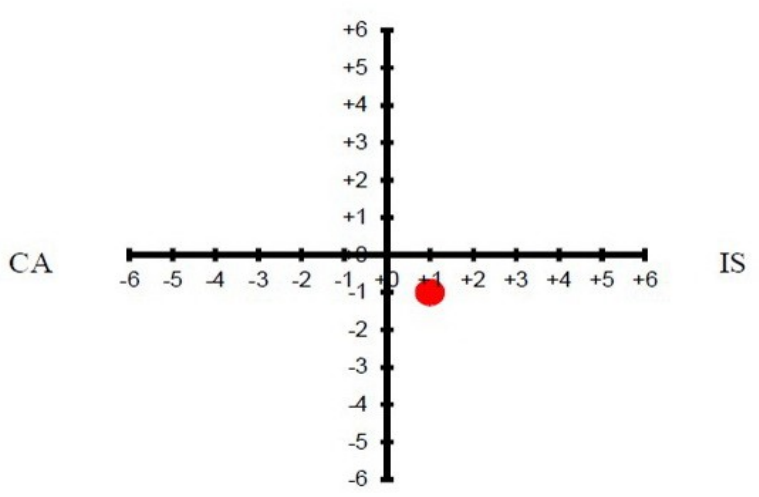

Defensive ES Competitive

Figure 3. Strategic Position of Farm C Based on SPACE Matrix

phase for the company in the formulation of competitive strategy, namely: 1) decide where the company has the best chance to win the competition; 2) develop the attributes of products and services that have a strong appeal to consumers; 3 ) establish initiatory movements and neutralizing reactions by rivals (Hartono, 2011; Garthinda and Aldianto, 2012). Based on the customer satisfaction analysis on milk goat quality there are attributes that are regarded as important information to attract consumers' namely nutritional content, expiry date, accessibility, and product design. Farmers should redesign their product' packages or improve their marketing strategies to satisfy the consumer' needs. Farmers may add their sole agents or milk outlets, and distribute their products closer to their prospective consumers.

\section{Grand Strategy Matrix Analysis}

Developing a grand strategy matrix involves examining a company's ability to grow quickly or slowly while assessing strengths and weaknesses. The first quadrant represents strategies for companies with a strong competitive position and thriving market growth. Companies with a weak competitive position in a fast emerging market are positioned in the second quadrant. The third provides strategies relevant to companies in a slowly growing industry with less competition, while the fourth quadrant lists strategies for companies with a strong competitive position in a 


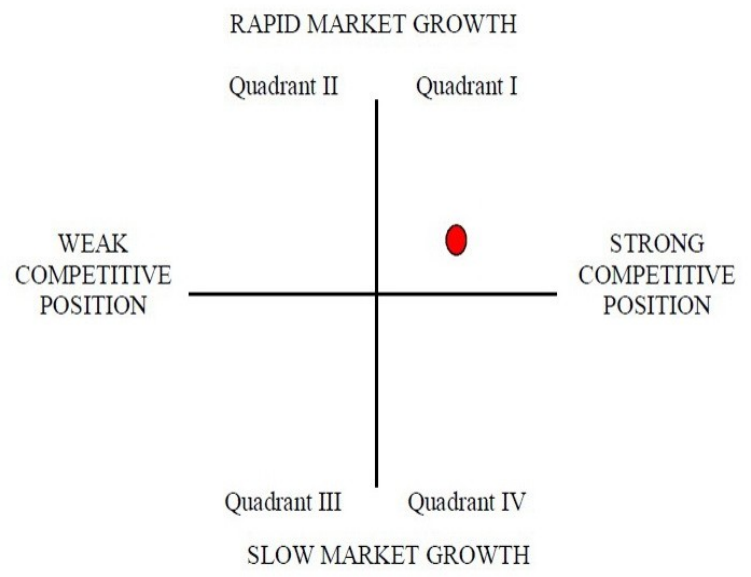

Figure 4. Strategic Position of Goat Milk Farms in Bogor Regency Based on Grand Strategy Matrix

slowly growing industry.

Grand Strategy Matrix analysis (Figure 4) shows that dairy goat farms in Bogor Regency are in quadrant I. It was revealed that dairy goat farms were in an excellent position to take advantage of the opportunities, overcome internal weaknesses and avoiding multiple external threats. Dairy goat farms have many resource advantages, despite facing various threats. The best strategies to be selected for dairy goat farms were market penetration and product development.

Farmers may also apply strategy prospector, it is the most aggressive of the four strategies. It typically involves active programs to expand into new markets. The strength of this strategy lies in the ability to respond quickly to any signs of market opportunity, trends, and its ability to create new products with little research or analysis.

\section{CONCLUSION}

The primary internal factors for the development of dairy goat farms is the quality of goat's milk, as well as the characteristics of farmers such as creativity, innovative and the entrepreneurial spirit. Meanwhile, the high satisfaction of customers was the primary external factors as an opportunity for dairy goat farms. However, major threat is the continuity of young stocks availability from supplier, as there is no guarantee for regular support. Dairy goat farms in Bogor region were in excellent position to utilize its internal strengths to take profitable external opportunities, and examine internal weaknesses and avoid multiple external threats. Dairy goat farms tend to have greater strengths than weaknesses and poses greater threats than opportunities. Despite facing various threats, dairy goat farms have resource advantages. The best strategies to be selected for the good performance of its farms were market penetration and product development.

\section{REFERENCES}

Aisyah, S.A., B. Sanim and A. Maulana. 2013. Strategi pengembangan usaha sapi potong: studi kasus CV Mitra Tani Farm. J. Man. Agribisnis. 10(2):109-116.

Astuti, R., Marimin, R. Poerwanto, Y. Machfud and Arkeman. 2010. Kebutuhan dan struktur kelembagaan rantai pasok buah manggis. Integrita-J. Man. Bisnis. 3(1):99-115.

Borocki, J. 2011. Process of applying modified SPACE model for defining company's strategy. Int'l J. Industrial Eng. Man. 2(2):61-68.

[BPS] Badan Pusat Statistik Kabupaten Bogor. 2015. Statistik Daerah Kabupaten Bogor Tahun 2015.

Capps, C.J. and M.D. Glissmeyer. 2012. Extending the competitive profile matrix using internal factor evaluation and external factor evaluation matrix concepts. J. Agric. Business Res. 28(5):1059-1062

Costa, R.G., H.L.B.D Monte, E.C.P. Filho, E.V.H. Júnior, G.R.B. da Cruz and M.P.C. Menezes. 2010. Typology and characterization of goat milk production systems in the Cariris Paraibanos. R. Bras. Zootec. 39(3):656-666.

Cox, M. 2015. A basic guide for empirical environmental social science. Ecol. and Society 20 (1): 63-70.

Cyrilla, L., B.P. Purwanto, D.A. Astuti, A. Atabany and A. Sukmawati. 2015. Improving goat milk quality for dairy goat farm development. Med. Pet. 38(3):204-211.

David, M.E., F.R. David and F.R. David. 2009. The Quantitative Strategic Planning Matrix (QSPM) applied to a retail computer store. Coastal Business J. 8(1):42-52.

Delaney, C. 2012. Guide to starting a commercial goat dairy. UVM Center for Sustainable Agriculture, Vermont USA.

Deshpande, A. 2012. Supply chain management dimensions, supply chain performance and 
organizational performance: an integrated framework. Int'l J. Business Man. 7 (8):1-18.

Ditjen Industri Agro dan Kimia. 2009. Road Map Industri Susu. Departemen Perindustrian Republik Indonesia, Jakarta.

Ditjen Peternakan and Kesehatan Hewan. 2011. Rencana Strategis Direktorat Jenderal Peternakan dan Kesehatan Hewan 20112014. Kementerian Pertanian Republik Indonesia, Jakarta.

Garthinda, D. and L. Aldianto. 2012. Business strategy recommendation for Warung Lepak restaurant using Quantitative Strategic Planning Matrix (QSPM). Indonesian J. Business Admin. 1(3):137-145.

Harisudin, M. 2011. Competitive profile matrix sebagai alat analisis strategi pemasaran produk atau jasa. J. Sosial Ekonomi Pertanian Agribisnis. 7(2):80-84

Hartono. 2011. Development strategy for the tapis traditional woven fabric industry. Int'l J. Admin. Sci. Org. 18(2):152-165

Ishak, N.M. and A.Y.A. Bakar. 2014. Developing sampling frame for case study: challenges and conditions. World J. Edu. 4(3):29-35.

Lie, H., K.M. Rich, L.R. Kurwijila and A.M. Jervell. 2012. Improving smallholder livelihoods through local value chain development: a case study of goat milk yogurt in Tanzania. Int'l Food and Agribusiness Man. Rev. 15(3):55-86

Midau, A., A. Kibon, M.S. Morrupa and C.
Augustine. 2010. Acceptability and consumption of goat milk in Adamawa State, Nigeria: a case study of Mubi North and Mubi South local government areas. J. Agric. Soc. Sci. 6:11-13.

Nurlaelasari, N., M. Yopita, and A. Durahman. 2014. Corporate strategic management analysis of PT Ultrajaya Milk Industry and Trading Company Tbk. Int'l J. Sci. Res. 3(6):2178-2183.

O'Regan, N., G. Kling, A. Ghobadian and L. Perren. 2012. Strategic positioning and grand strategies for high-technology SMEs. Strategic Change. 21(5-6):199-215.

Safari, H., A. Behrooz, H. Bazargani, and M.H. Soleimani-Sarvestani. 2013. Proposing a framework for strategic positioning using an integrated method. World App. Prog. 3(4):150-163.

Shahroudi, K. and S. Naimi. 2014. The impact of brand image on customer satisfaction and loyalty intention (case study: consumer of hygiene products). Int'l J. Edu. Innovation Res. 3(1):57-61.

Utami, H.D. 2014. Consumer behavior toward goat milk and its processed products in Malang, Indonesia. J. Int'l. Food and Agribusiness Marketing. 26(1):1-12.

Wheelen, T.L. and J.D. Hunger. 2010. Strategic Management and Business Policy: Achieving Sustainability $12^{\text {th }}$ Ed. Prentice Hall, Pearson Education Asia Pte Ltd, New Jersey. 